\title{
PROTOTIPE SECURITY DOOR LOCK SYSTEM MENGGUNAKAN PASSWORD BERBASIS MIKROKONTROLER ATMEGA328
}

\author{
Ageng Setiani Rafika ${ }^{1}$ \\ Purnomo Satria Nugroho ${ }^{2}$ \\ Ristian Raharjo ${ }^{3}$
}

Jl. Jend. Sudirman No. 40 Modern Cikokol Tangerang 15117

E-mail:

agengsetianirafika@raharja.info, purnomosatria@raharja.info, ristian@raharja.info

\begin{abstract}
ABSTRAK
Keamanan adalah keadaan bebas dari bahaya. Istilah ini bisa digunakan dalam hubungannya kepada kejahatan, segala bentuk kecelakaan, dan lain-lain. Keamanan merupakan topik yang luas termasuk keamananan nasional terhadap serangan teroris, keamanan komputer terhadap hacker, cracker ataupun virus, keamanan rumah terhadap pencuri, penyusup atau lainnya, keamanan finansial terhadap kehancuran ekonomi dan banyak situasi yang berhubungan. Seiring dengan meningkatnya tindakan kejahatan khususnya dalam sebuah ruangan, dengan semakin pesatnya kemajuan teknologi pada saat ini, maka sangatlah dibutuhkan sebuah sistem keamanan pintu ruangan menggunakan model pengaman password pada pintu untuk mencegah orang-orang yang tidak berhak memasuki ruangan yang bukan miliknya. Dari permasalahan tersebut maka dirancanglah prototipe sistem keamanan pintu ruangan menggunakan password berbasis mikrokontroler ATmega328 sebagai bentuk keamanan yang lebih baik dari yang sudah ada sebelumnya. Sistem keamanan menggunakan password ini menjadi sangat penting untuk meningkatkan keamanan pintu ruangan dari sistem konvensional. Sehingga sistem ini lebih efektif dalam hal pengamanan, dan lebih efisien dalam hal biaya dan perawatan.
\end{abstract}

Kata Kunci: Keamanan, Pintu, Password, Mikrokontroler ATmega328.

\begin{abstract}
Security is a state of being free from danger. The term is commonly used in relation to the crime, all forms of accidents, and others. Security is a broad topic, including national's security against terrorist attacks, computer security against hackers, crackers or virus, home security against burglars, intruders or other financial security against economic collapse and many related situations. Along with the increase in crime, especially in a room, with the rapid advancement of technology today, it is needed a room door security system using password security model of the door to prevent people who are not entitled to enter a room that was not hers. Of these problems then designed a prototype system using password security room doors based microcontroller ATmega328 as a form of security that is better than what already exists. The security system uses this password becomes very important to improve the security door of the room of a conventional system. So the system is more effective in terms of security, and more efficient in terms of cost and maintenance.
\end{abstract}

Keywords: Security, Door, Password, ATmega328 microcontroller

Vol.2 No.2 - Agustus 2016 


\section{PENDAHULUAN}

Keamanan adalah keadaan bebas dari bahaya. Istilah ini bisa digunakan dengan hubungan kepada kejahatan, segala bentuk kecelakaan, dan lain-lain. Keamanan merupakan topik yang luas termasuk keamananan nasional terhadap serangan teroris, keamanan komputer terhadap hacker atau cracker, keamanan rumah terhadap maling dan penyusup lainnya, keamanan finansial terhadap kehancuran ekonomi dan banyak situasi berhubungan lainnya.

Perkembangan teknologi saat ini sangat pesat khususnya di bidang komputerisasi dan elektronika. Teknologi yang dikembangkan bertujuan untuk memberikan keamanan, baik keamanan diri maupun keamanan terhadap barang-barang berharga dan dokumendokumen penting agar terhindar dari tindak kriminalitas, khususnya tindakan pencurian. Barang-barang dan dokumen-dokumen penting biasanya disimpan dalam suatu ruangan khusus agar tidak diambil oleh orang-orang yang tidak berhak. Menanggulangi hal tersebut, pihak perusahaan maupun instansi harus menambah pengeluaran untuk membayar sejumlah petugas penjaga pintu.

Sangat berarti sekali jika proses pengawasan pintu dibantu dengan penerapan teknologi, agar efisien dan proses pengawasannya lebih terstruktur dan lebih baik. Lemahnya sistem keamanan ruangan yang konvensional untuk menjaga barang-barang berharga dan dokumen-dokumen penting tersebut, memberikan peluang dan kesempatan kepada orang yang tidak berhak mengambil dan mencuri barang-barang tersebut. Pengawasan atau pemantauan yang tidak efisien mengakibatkan terjadi kelalaian dari petugas penjaga pintu ruangan, dan akan rentan terhadap tindak kejahatan. Dengan kondisi demikian, dapat dikatakan sistem tidak memenuhi syarat-syarat dalam suatu keamanan.

Dalam penelitian ini peneliti menggunakan input password sebagai sistem keamanan pintu ruangan yang berbasis mikrokontroler Atmega328 dengan output unlock solenoid, display status di LCD serta notifikasi buzzer. Alat ini dirancang menyerupai pintu ruangan pada umumnya yang dilengkapi komponen berupa keypad matrix 4x3, mikrokontroler ATmega328, LCD 16x2, dan buzzer yang dijadikan sebagai notifikasi status untuk mendukung kinerja keamanan pintu tersebut.

\section{PERMASALAHAN}

Sepintas keamanan ruangan dianggap sepele dalam implementasinya hanya dengan menambahkan kunci pada pintu ruangan sudah dapat dikatakan sebuah ruangan itu aman tanpa kemungkinan buruk yang mungkin saja bisa terjadi. Padahal ancaman kemananan pada ruangan seharusnya menjadi perhatian khusus oleh sebuah instansi atau perusahaan karena dalam sebuah ruangan banyak tersimpan data-data penting maupun barang penting yang jika hilang/dicuri orang akan merugikan instansi/perusahaan tersebut. Pada cara konvensional keamanan ruangan masih terdapat banyak celah diantaranya:

1. Pintu ruangan yang hanya dibekali kunci sebagai media pengamannya bisa di duplikasi dan di perbanyak, sehingga menjadi peluang untuk orang yang tidak bertanggung jawab masuk dan mencuri data di dalam ruanagan.

2. Kecerobohan atau kekhilafan pemilik ruangan juga menjadi perhatian dalam keamanan ruangan ini yaitu, pemilik ruangan lupa menaruh kunci ruangan ataupun kunci tertinggal di rumah, yang berakibat pemilik tidak bisa masuk ke dalam ruangan.

3. Adanya kemungkinan pembobolan pintu ruangan dengan cara mencongkel pintu ataupun dengan cara lain dikarenakan pintu ruangan tersebut tidak dilengkapi

Vol.2 No.2 - Agustus 2016 
dengan sistem alarm sebagai notifikasi adanya ancaman keamanan pada ruangan tersebut.

Sistem yang lebih canggih dan modern untuk keamanan ruangan sangat dibutuhkan dan perlu diterapkan dalam instansi/perusahaan untuk memberi rasa aman kepada pemilik ruangan dan mempermudah kinerja sistem keamanan pintu ruangan dengan pemanfaatan mikrokontroler dan perangkat android.

\section{LITERATURE REVIEW}

Banyak penelitian yang sebelumnya dilakukan mengenai sistem keamanan pintu ruangan menggunakan password. Dalam upaya mengembangkan dan menyempurnakan sistem ini perlu dilakukan studi pustaka (literature review) sebagai salah satu dari penerapan metode penelitian yang akan dilakukan. Diantaranya adalah mengidentifikasikan kesenjangan, menghindari pembuatan ulang, mengidentifikasikan metode yang pernah dilakukan, meneruskan penelitian sebelumnya, serta mengetahui orang lain yang spesialisasi dan area penelitiannya sama dibidang ini. Beberapa Literature review tersebut adalah sebagai berikut:

1. Penelitian ini dilakukan oleh Moch Firmansyah dari STMIK Raharja pada tahun 2009 yang berjudul "Akses Ruangan Digitally Synthesizer Laboratory (DSL) Dengan Menggunakan Metode MPP (Microcontroller Password Protection) menggunakan mikrokontroler AT89S205". Keamanan merupakan hal yang vital dalam sistem yang diteliti ini, karena itu digunakan metode Microcontroller Password Protection (MPP) yaitu perlindungan yang berupa kode password berbasis mikrokontroler sebagai pengolah data. Dalam hal membuka dan menutup pintu pada ruangan Digital Synthesizer Laboratory (DSL) dengan tingkat pengamanan yang memadai. Maka digunakanlah komponen yang dapat mengolah sistem tersebut, tetapi dalam bentuk yang tidak terlalu besar. Sehingga digunakanlah mikrokontroler sebagai pemroses pengendalian utama dan penyimpan kode password yang akan digunakan sebagai kode akses pada ruangan tersebut. Pekerjaan untuk membuka dan menutup pintu pada ruangan tersebut sepenuhnya dilakukan oleh mikrokontroler, dan akan ditampilkan display interaksi pada pengguna melalui Liquid Crystal Display (LCD). Tujuan dari pembuatan sistem ini adalah untuk membuat sistem keamanan dengan hak akses terbatas sehingga tidak setiap orang bisa mengetahui kombinasi tombol yang digunakan.

2. Penelitian ini dilakukan oleh Fitri Apriyani dari STMIK Raharja pada tahun 2012 yang berjudul "Sistem Keamanan Pintu Menggunakan Password Berbasis Mikrokontroller AT89S51". Peneliti menggunakan password sebagai akses masuk/keamanan pintu dengan pemanfaatan mikrokontroler AT89S51. Input yang diberikan berupa keypad sebagai media yang berfungsi untuk memasukkan Password, Motor DC sebagai penggerak pintu saat membuka dan menutup kembali. Sedangkan mikrokontroler digunakan sebagai kontrol utaman pada alat ini.

3. Penelitian ini dilakukan oleh Gustasari dari STMIK Raharja pada tahun 2014 yang berjudul "Perancangan Sistem Smartcard Sebagai Pengaman Pintu Menggunakan Rfid Berbasis Arduino". RFID adalah teknologi yang masih baru, dan akan terus berkembang, seiring dengan kemajuan teknologi rangkainan terintegrasi, maka dapat dipastikan bahwa RFID TAG dapat diaplikasikan dalam berbagai bidang. Sistemsistem RFID menawarkan peningkatan efisien dalam penggendalian inventory control dalam pengindektification barang ataupun buku didalam perpustakaan ataupun absensi kelas. RFID (Radio Frequency Identification) merupakan proses identifikasi seseorang atau objek dengan menggunakan frekuensi transmisi radio. RFID bisa 
digunakan untuk menyimpan dan menerima data secara jarak jauh dengan menggunakan suatu piranti yaitu RFID TAG (transponder), RFID diaplikasikan sebagai pembuka pintu keluar masuk pada ruangan PERGURUAN TINGGI RAHARJA yang dikontrol oleh ARDUINO UNO.

4. Penelitian ini dilakukan oleh Mohammad Arif Dwi Cahyo dari STMIK Raharja pada tahun 2014 yang berjudul "Desain Prototipe Smart Voice Device Pintu Ruangan Menggunakan Raspberry Pi Pada Perguruan Tinggi Raharja". Suara atau voice merupakan salah satu ciri khas yang dimiliki manusia yang tidak dapat disamai oleh orang lain/ manusia lain. Ini yang melatarbelakangi peneliti untuk menjadikan suara sebagai akses untuk membuka dan mengunci ruangan. Dengan memanfaatkan tekologi mikrokonroler yang mulai berkembang pesat, peneliti menggunakan Raspberry Pi untuk membangun sistem keamanan dengan input suara ini.

5. Penelitian ini dilakukan oleh Agung Alpurqon dari STMIK Raharja pada tahun 2014 yang berjudul "Sistem Pengendali Pintu Pagar Secara Otomatis Menggunakan Aplikasi Voice Command Pada Smartphone Android OS". Android merupakan teknologi canggih yang menjadi daya tarik orang lain untuk menggunakannya. Peneliti menggunakan input suara untuk mengontrol buka dan tutup pintu pagar, dengan android sebagai media input dalam sebuah smartphone. Peneliti merancang sebuah sistem kontrol pintu pagar menggunakan rangkaian mikrokontroler yang diprogram menggunakan bahasa program terperinci.

\section{PEMBAHASAN}

Untuk bisa menjalankan sistem keamanan pintu ruangan, alat ini dilengkap berbagai modul dan komponen diantaranya adalah rangkaian keypad matrix, mikrokontroler ATmega328, rangkaian driver penggerak solenoid, LCD, dan Buzzer. Keypad matrix yang digunakan adalah keypad dengan ukuran 4x3 yang menjadi media input password unlock pintu. Ketika password yang dimasukkan benar, maka mikrokontroler akan menggerakan kumparan solenoid untuk unlock pintu, sebaliknya jika password salah kumparan tidak akan bergerak.

Untuk output digunakan LCD 16x2 sebagai penunjuk status benar atau tidaknya password yang diinput. Jika password yang diinputkan benar maka akan muncul display di LCD berupa tulisan "Password Benar, Silahkan Masuk" dan jika password yang di input salah, maka LCD akan memunculkan tulisan "Password Salah, Silahkan Coba Lagi", dan buzzer akan berbunyi sebagai notifikasi password salah. Agar sistem keamanan ruangan ini dapat bekerja sesuai dengan fungsi yang diharapkan tentu saja dibutuhkan pemrograman khusus, oleh karena itu maka diperlukan sebuah program yang dibangun menggunakan bahasa basic yang kemudian dikonversi kedalam bentuk yang dapat dikenali oleh mikrokontroller. Dan kemudian dimasukkan kedalam mikrokontroler proses memasukkan program ini disebut Injection. Data yang diterima oleh mikrokontroler tersebut merupakan data digital hasil konversi dari Analog To Digital Converter (ADC). Untuk memindahkan program dari komputer ke dalam mikrokontroler dibutuhkan sebuah alat yang bernama Downloader yang berfungsi sebagai perantara untuk pengisisan program tadi. Adapun diagram sistem blok secara keseluruhan ditunjukkan pada gambar 1 : 

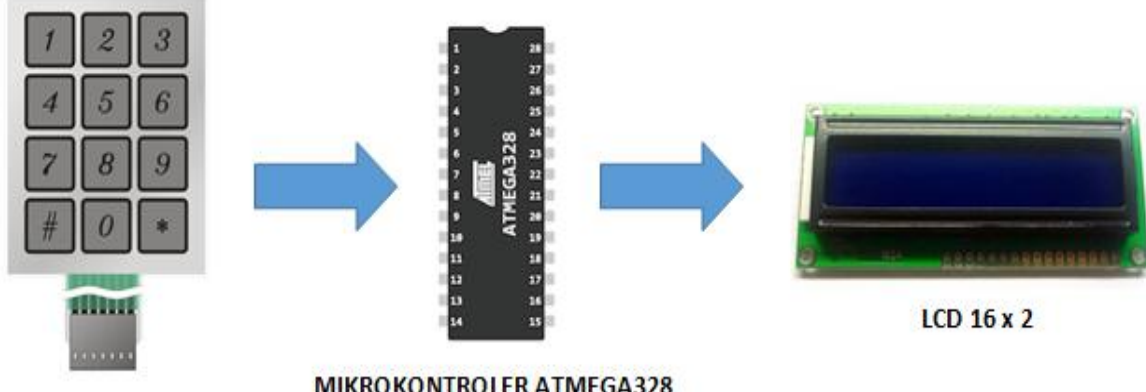

LCD $16 \times 2$

KEYPAD $4 \times 3$

MIKROKONTROLER ATMEGA328

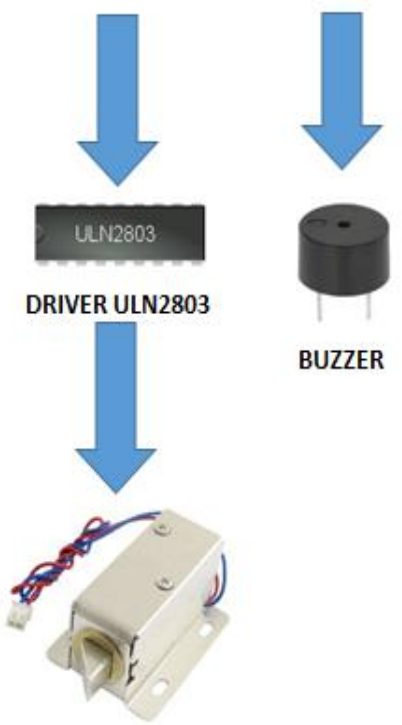

SOLENOID

Gambar 1 Diagram Blok Rangkaian

Vol.2 No.2 - Agustus 2016 


\section{FLOWCHART SISTEM YANG DIUSULKAN}

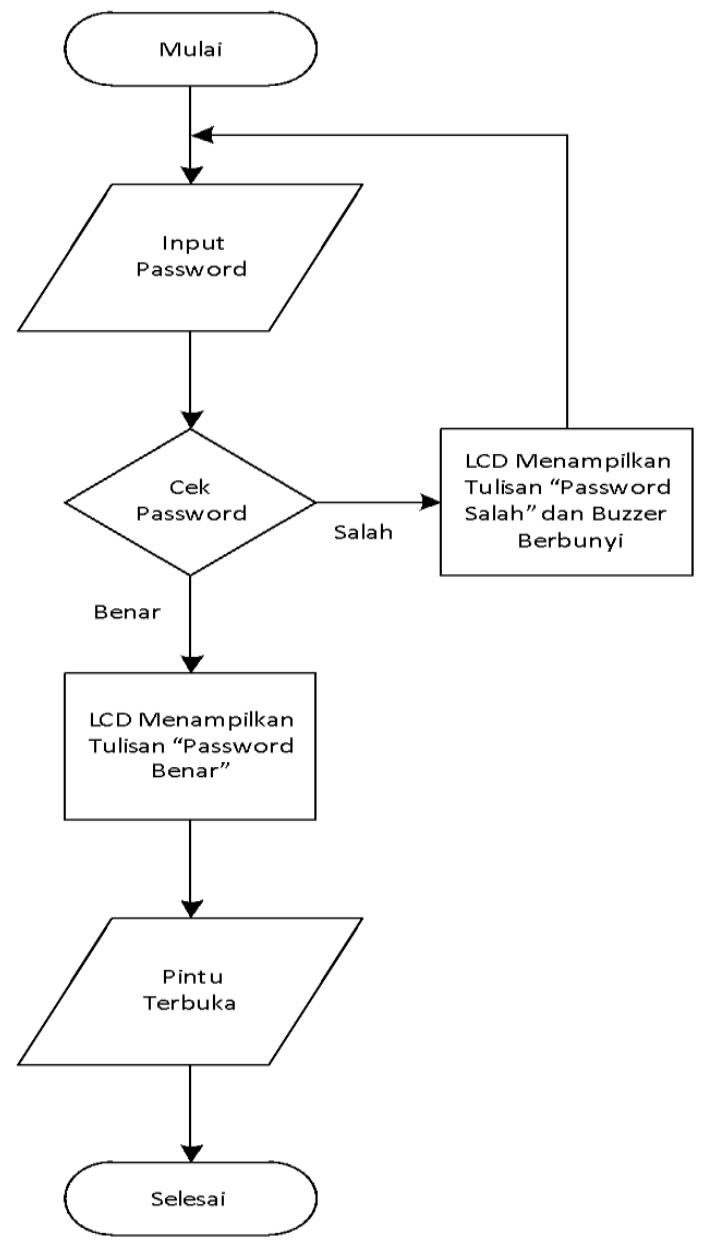

\section{Gambar 2 Flowchart Sistem Keamanan Pintu Ruangan Yang Diusulkan}

Sistem diawali dengan start yang berarti sistem akan mulai bekerja, kemudian user memasukkan password untuk mendapat akses unlock pintu ruangan. Jika password yang dimasukkan benar maka LCD akan menampilkan tulisan "Password Benar, Silahkan Masuk". Sebaliknya jika password salah maka LCD akan menampilkan tulisan "Password Salah, Silahkan Coba Lagi" bersamaan dengan bunyi buzzer dan sistem kembali mengulang proses dari awal.

Jika Mikrokontroler mendeteksi password yang di masukkan melalui papan keypad matrix benar, maka mikrokontroler kemudian mengolah data dan memproses perintah yang akan dikerjakan oleh rangkaian LCD berupa tulisan "Password Benar, Silahkan Masuk" Lalu melakukan proses rangkaian driver solenoid untuk menggerakkan kumparan untuk unlock pintu. Bila input password pada keypad matrix salah, maka mikrokontroller mengintuksikan pada LCD untuk menampilkan tulisan "Password Salah, Silahkan Coba Lagi" lalu mikrokontroler juga mengintruksikan buzzer untuk berbunyi sebagai notifikasi bahwa user salah memasukkan password dan tidak mendapatkan akses untuk unlock pintu ruangan. Lalu kondisi kembali ke awal. 


\section{IMPLEMENTASI}

\section{Pengujian Rangkaian Mikrokontroler dan LCD}

Pengujian pada rangkaian mikrokontroler ini dilakukan dengan dihubungkan langsung dengan modul LCD. Yang kemudian diberikan tegangan kerja sebesar 5 volt. Dan dilakukan pemutaran pada trimpot $10 \mathrm{~K} \Omega$, untuk mendapatkan kecerahan display yang sesuai dengan kebutuhan. Uji coba selanjutnya yaitu dengan mencoba memasukkan listing program sederhana untuk tampilan awal LCD. Setelah listing program dimasukkan kedalam mikrokontroler ATmega328 langkah selanjutnya adalah melihat tampilan LCD yang sudah sesuai dengan yang diinginkan. Maka sudah dipastikan rangkaian mikrokontroler dan LCD dapat digunakan. Adapun penggalan dari listing program yang dipakai dalam serangkaian uji coba tersebut adalah sebagai berikut:

\section{Listing Program Tampilan Awal LCD 1:}
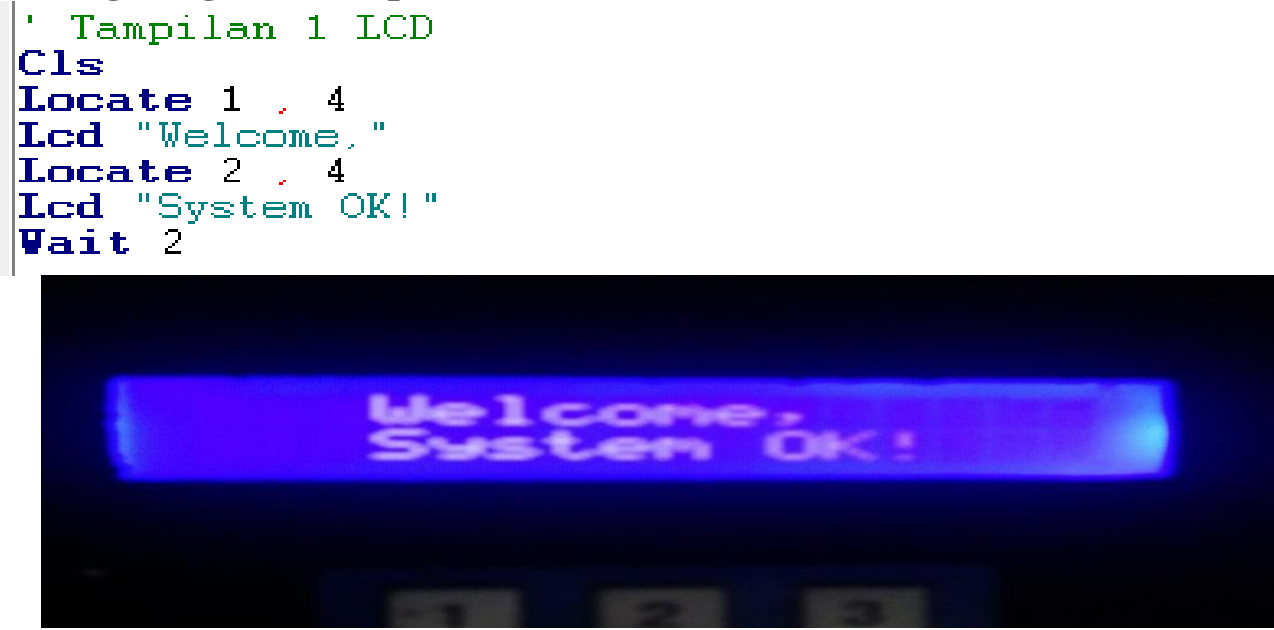

Gambar 3 Tampilan Awal LCD 1

2. Listing Program Tampilan Awal LCD 2:
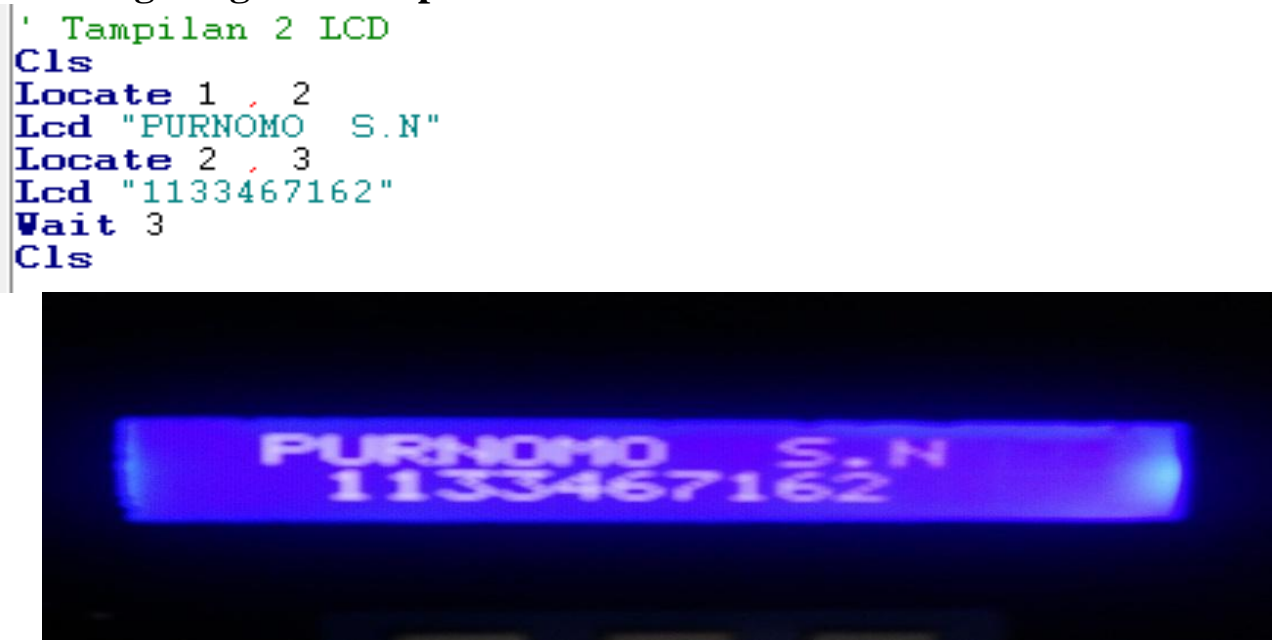

Gambar 4 Tampilan Awal LCD 2

\section{Pengujian Rangkaian Keypad Matrix}

Keypad digunakan untuk memasukkan angka-angka dan instruksi yang telah ditentukan oleh program yang ada dalam mikrokontroler yang kemudian dibandingkan antara hasil penekanan keypad dan data yang sudah tersimpan dalam memori program. Dari keseluruhan pin koneksi keypad terdapat tiga buah pin yang merupakan $\mathrm{C} 0, \mathrm{C} 1, \mathrm{C} 3$

Vol.2 No.2 - Agustus 2016 
yang mempunyai tugas sebagai jalur scanning ataupun akan secara bergantian mendapatkan logika " 0 " sehingga data akan berbeda - beda. Dari hasil pengujian didapatkan nilai yang akan di baca oleh mikrokontroler akan ditampilkan berupa nilai biner pada tabel 4.8 .

Prinsip kerja dari rangkaian ini adalah menghubungkan antara kolom dan baris yang akan bertemu pada suatu titik, pertemuan antara kedua titik inilah yang ditandai dengan angka dan simbol yang disusun secara berurutan secara umum.

Tabel 1 Data Hasil Pengujian Keypad

\begin{tabular}{|c|c|c|}
\hline Scanning & Angka/Simbol & Data \\
\hline \multirow{4}{*}{ Scan 1 } & Angka 1 & $11101110 \mathrm{~B}$ \\
\cline { 2 - 3 } & Angka 4 & $11011110 \mathrm{~B}$ \\
\cline { 2 - 3 } & Angka 7 & $10111110 \mathrm{~B}$ \\
\cline { 2 - 3 } & Simbol * & $01111110 \mathrm{~B}$ \\
\hline \multirow{4}{*}{ Scan 2 } & Angka 2 & $11101101 \mathrm{~B}$ \\
\cline { 2 - 3 } & Angka 5 & $11011101 \mathrm{~B}$ \\
\cline { 2 - 3 } & Angka 8 & $10111101 \mathrm{~B}$ \\
\cline { 2 - 3 } & Angka 0 & $01111101 \mathrm{~B}$ \\
\hline \multirow{4}{*}{ Scan 3 } & Angka 3 & $11101011 \mathrm{~B}$ \\
\cline { 2 - 3 } & Angka 6 & $11011011 \mathrm{~B}$ \\
\cline { 2 - 3 } & Angka 9 & $10111011 \mathrm{~B}$ \\
\cline { 2 - 3 } & Simbol \# & $01111011 \mathrm{~B}$ \\
\hline
\end{tabular}

Setelah melihat hasil yang didapatkan dalam pengujian tersebut, maka dapat diambil kesimpulan bahwa rangkaian keypad bekerja sesuai dengan yang diinginkan.

\section{Pengujian Buzzer}

Pada pengujian buzzer ini dilakukan dengan menghubungkan rangkaian transistor NPN dengan buzzer yang diberikan tegangan kerja sebesar 5 VDC. Rangkaian transistor ini digunakan sebagai sakelar elektronik yang mampu untuk memutus atau menyambungkan tegangan pada buzzer, dalam rangkaian ini digunakan dioda sebagai penyearah tegangan dan resistor yang dihubungkan pada rangkaian mikrokontroler. Dari hasil pengujian diperoleh data seperti pada Tabel 4.9 berikut ini :

\section{Tabel 2 Pengukuran Tegangan Pada Buzzer}

\begin{tabular}{|c|c|c|}
\hline No & Tegangan (Volt) & Keterangan \\
\hline 1 & $5 \mathrm{~V}$ & Tidak Berbunyi \\
\hline 2 & $6 \mathrm{~V}$ & Tidak Berbunyi \\
\hline 3 & $7 \mathrm{~V}$ & Tidak Berbunyi \\
\hline 4 & $8 \mathrm{~V}$ & Berbunyi \\
\hline 5 & $9 \mathrm{~V}$ & Berbunyi \\
\hline
\end{tabular}

Setelah melihat hasil yang didapatkan dalam pengujian tersebut, maka dapat diambil kesimpulan bahwa buzzer bekerja sesuai dengan yang diinginkan. 


\section{Perancangan Prototipe}

Prototipe sistem keamanan pintu ruangan ini menggunakan keypad matrix 4x3 berbasis mikrokontroler Atmega328 dengan output unlock kumparan solenoid, tampilan LCD dan notifikasi buzzer. Dalam perancangan disusun menyerupai pintu ruangan yang umum digunakan. Alat ini dilengkapi dengan bebrapa komponen seperti: keypad matrix 4x3, mikrokontroler ATmega328, rangkaian driver solenoid, LCD 16x2, dan Buzzer yang dijadikan sebagai notifikasi. Bahan yang digunakan dalam perancangan prototipe tebuat dari pintu plastik yang digunakan sebagai objek pada sistem keamanan ini.

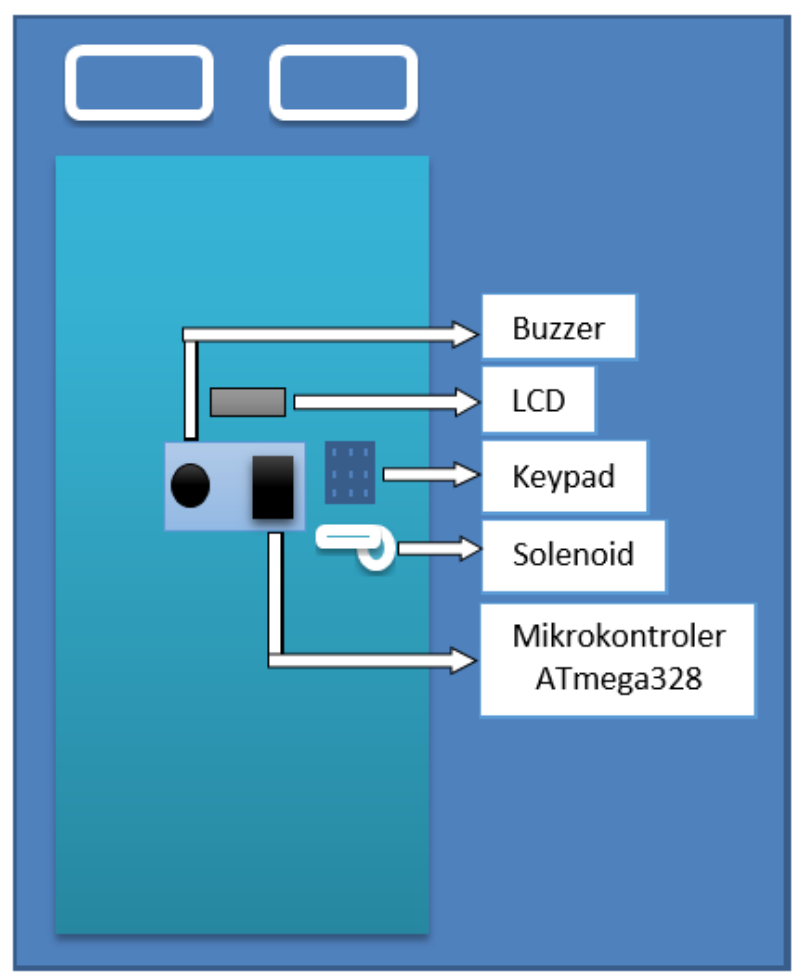

Gambar 5 Perancangan Prototipe 


\section{CARA KERJA ALAT}

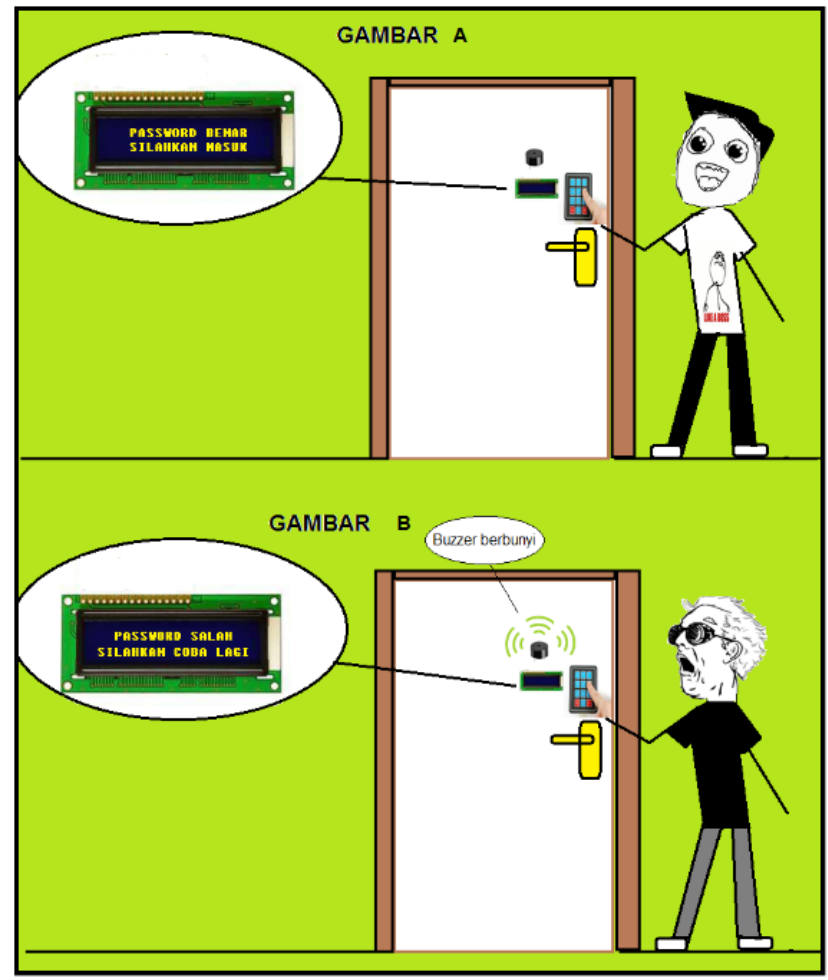

Gambar 6 Cara Kerja Alat

Perhatikan pada gambar diatas. User menekan tombol password pada keypad matrix $4 \times 3$ yang terdapat pada sisi handle tuas pintu, lalu mikrokontroller memproses input password tadi menjadi perintah berupa unlock kumparan solenoid menggunakan rangkaian driver ULN2803. Yang kemudian menjadi output display tulisan di LCD yang muncul berupa tulisan "Password Benar, Silahkan Masuk".

Sebaliknya pada gambar kedua, user yang bukan pemilik ruangan tersebut memeasukkan password yang salah lalu mikrokontroler memproses input password yang salah tersebut menjadi display tulisan di LCD berupa tulisan "Password Salah, Silahkan Coba Lagi" kemudian buzzer berbunyi.

\section{KESIMPULAN}

Dari hasil perancangan alat dan pembahasan sistem keamanan pintu ruangan di atas dapat diambil beberapa kesimpulan, diantaranya:

1. Menciptakan sistem keamanan pintu ruangan menggunakan password berbasis mikrokontroler ATmega328 dengan menghasilkan output tampilan dan notifikasi yang dirancang untuk memberikan keamanan yang lebih baik sehingga ditemukan solusi terbaik bahwa mikrokontroler memiliki tingkat kehandalan dan kestabilan yang tinggi dan hasil lebih efektif.

2. Proses konfigurasi program ke dalam mikrokontroler ATmega328 mempengaruhi kinerja sistem keamanan password untuk memberikan keamanan yang lebih baik dengan menghasilkan output tampilan dan notifikasi.

3. Dari sistem keamanan pintu ruangan yang telah dirancang dapat memberikan keamanan yang lebih baik melalui sistem password dan output berupa tampilan dan notifikasi, hasil keamanan yang didapat lebih efektif dan efisien dibanding dengan keamanan konvensional. 


\section{DAFTAR PUSTAKA}

[1] Moch Firmansyah. (2009). Akses Ruangan Digitally Synthesizer Laboratory (DSL) Dengan Menggunakan Metode MPP (Microcontroller Password Protection) menggunakan mikrokontroler AT89S205. Tugas Akhir. Perguruan Tinggi Raharja.

[2] Fitri Apriyani. (2012).Sistem Keamanan Pintu Menggunakan Password Berbasis Mikrokontroller AT89S51. Tugas Akhir. Perguruan Tinggi Raharja.

[3] Gustasari.(2014).Perancangan Sistem Smartcard Sebagai Pengaman Pintu Menggunakan Rfid Berbasis Arduino. Tugas Akhir. Perguruan Tinggi Raharja.

[4] Mohammad Arif Dwi Cahyo. (2014).Desain Prototipe Smart Voice Device Pintu Ruangan Menggunakan Raspberry Pi. Tugas Akhir. Perguruan Tinggi Raharja.

[5] Agung Alpurqon.(2014). Sistem Pengendali Pintu Pagar Secara Otomatis Menggunakan Aplikasi Voice Command Pada Smartphone Android OS. Tugas Akhir. Perguruan Tinggi Raharja. 